\title{
Anesthetic agent etiomidate induces apoptosis in N2a brain tumor cell line
}

\author{
HONG-TAO CHEN ${ }^{1}$, JUN ZHOU ${ }^{2}$, YOU-LING FAN ${ }^{3}$, CHUN-LIANG LEI ${ }^{1}$, \\ BAO-JIN LI ${ }^{1}$, LI-XIN FAN ${ }^{1}$, LI XU $^{1}$, MING XU ${ }^{1}$, XIU-QIN HU $^{1}$ and ZHI-YING YU ${ }^{1}$ \\ ${ }^{1}$ Department of Anesthesiology, The Eighth People's Hospital of Guangzhou Affiliated to Guangzhou Medical College, \\ Guangzhou, Guangdong 510060; ${ }^{2}$ Department of Anesthesiology, Affiliated Foshan Hospital of \\ Sun Yat-sen University, Foshan, Guangdong 528000; ${ }^{3}$ Department of Anesthesiology, \\ Central Hospital of Panyu District, Guangzhou, Guangdong 510060, P.R. China
}

Received September 12, 2017; Accepted November 17, 2017

DOI: $10.3892 / \mathrm{mmr} .2018 .9298$

\begin{abstract}
The present study identified the cytotoxic effects of etomidate on the N2a neuroblastoma cell line. Etomidate induced apoptosis in $\mathrm{N} 2 \mathrm{a}$ cells in a concentration-dependent manner, which was confirmed by western blotting and flow cytometry. Phase contrast microscopy was used to analyze the effect of etomidate on morphological characteristics. The number of the apoptotic cells was increased and confirmed by DAPI and PI staining, which served as a characteristic hallmark of apoptosis. Additionally, etomidate led to loss of mitochondrial membrane potential and resulted in the generation of reactive oxygen species in $\mathrm{N} 2 \mathrm{a}$ cells. The western blot analysis revealed that $\mathrm{N} 2$ a cells treated with etomidate had a significant modulation of pro-apoptotic proteins, includingpoly ADP-ribose polymerase (PARP), cleaved PARP, caspase-9 and procaspase-3. In conclusion, the present study determined that etomidate induced cytotoxic and apoptotic effects in $\mathrm{N} 2 \mathrm{a}$ brain tumor cells in vitro.
\end{abstract}

\section{Introduction}

Anesthesia has an important role in invasive medicinal procedures, as it allows for various surgeries to be performed, which may otherwise be impossible to complete due to intolerable pain $(1,2)$. The anesthetic procedures have been further classified based upon the need of medical application, such as general or local anesthesia $(3,4)$. In general anesthesia, the activity of the central nervous system is suppressed, which leads to an overall lack of sensation and unconsciousness, whereas in local anesthesia, the transmission of nerve impulses is blocked between the central nervous system and the part of the body

Correspondence to: Dr Jun Zhou, Department of Anesthesiology, Affiliated Foshan Hospital of Sun Yat-sen University, 3 Funan Road, Chancheng, Foshan, Guangdong 528000, P.R. China

E-mail: junzhou149@hotmail.com

Key words: etomidate, N2a cells, caspase-9, procaspase-3, caspase-9, cytotoxic effect which is targeted (5-9). Among the various anesthetic agents used today to sedate patients, etomidate has been identified as advantageous due to most favorable therapeutic index for single bolus administration $(10,11)$. Etomidate also provides advantages for induction of anesthesia in hemorrhagic shock conditions. It was administered intravenously in order to actasageneral anesthetic without affecting blood pressure and avoid any cardiovascular side effects (12-14). Etomidate has been previously identified to exert protection against cerebral ischemia, cause minimal ventilation suppression and reduce the liberation of histamines $(15,16)$. Previous studies have investigated the cytotoxic effect of etomidate (17-19); however, to the best of our knowledge no previous studies have investigated the underlying mechanism. The present study determined that etomidate induced apoptosis in the $\mathrm{N} 2 \mathrm{a}$ neuroblastoma cell line.

\section{Materials and methods}

Chemicals and reagents. The reagents and chemicals such as DMEM medium, MTT, dimethyl sulfoxide (DMSO), penicillinG, streptomycin, sodium bicarbonate, 4-(2-hydroxyethyl)-1-piperazineethanesulfonic acid (HEPES) and sodium pyruvate were obtained from Sigma-Aldrich; Merck Millipore, (Darmstadt, Germany). Fetal bovine serum (FBS) was purchased from Gibco (Thermo Fisher Scientific, Inc., Waltham, MA, USA) and Annex in V-FITC/PI Apoptosis Detection kit (cat. no. 556570) from BD Biosciences (San Jose, CA, USA).

Cell culture. N2a neuroblastoma cell line was obtained from the American Type Culture Collection (Manassas, VA, USA) and strictly grown as per the manufacturer's protocol. Dulbecco's modified Eagle's medium was supplemented with $10 \%$ fetal bovine serum (FBS), penicillin $\mathrm{G}(70 \mathrm{mg} / \mathrm{l})$, streptomycin $(100 \mathrm{mg} / \mathrm{l})$ and $\mathrm{NaHCO}_{3}(3.7 \mathrm{~g} / \mathrm{l})$. Cells were maintained at $37^{\circ} \mathrm{C}$ in a humidified $\mathrm{CO}_{2}$ incubator with $95 \%$ humidity and $5 \% \mathrm{CO}_{2}$.

Viability assay. The effect of etomidate on cell viability was investigated using an MTT assay. Briefly, in a 96-well plate, the 
cells were seeded at a density of $2 \times 10^{6}$ cells/well and allowed to grow for $24 \mathrm{~h}$. After $24 \mathrm{~h}$, the cells were treated with increasing concentrations of etomidate and were maintained for an additional $48 \mathrm{~h}$. The $2.5 \mathrm{mg} / \mathrm{ml}$ MTT was added $4 \mathrm{~h}$ prior to the termination of experiment. After $4 \mathrm{~h}$, the media was removed and formazan crystals were dissolved by adding $150 \mu \mathrm{l}$ DMSO per well. The absorbance was quantified using the Synergy MX microplate reader at $570 \mathrm{~nm}$.

Mitochondrial membrane potential. Cells at the density of $2 \times 10^{6}$ were seeded in $60 \mathrm{~mm}$ dish and maintained for $24 \mathrm{~h}$ after the $0,1,5$ and $10 \mu \mathrm{M}$ etomidate treatment was administered for $48 \mathrm{~h}$. Rhodamine-123 was added to the cells at $37^{\circ} \mathrm{C}$ for $30 \mathrm{~min}$ prior to the termination of the experiment. Finally, the cells were collected in respective tubes, centrifuged for $5 \mathrm{~min}$ at $400 \mathrm{x}$ g at $37^{\circ} \mathrm{C}$ and then washed three times with PBS. In flow tubes, the samples were finally transferred and resuspended in $500 \mu \mathrm{l}$ PBS. The inverted fluorescent microscope was used to visualize the mitochondrial depolarization level, the mitochondrial depolarization level was quantitatively analyzed by imaging software Image J (version 1.49; National Institutes of Health, Bethesda, MD, USA).

Colony formation assay. In a 6-well plate, N2a cells were seeded at $2.0 \times 10^{6}$ cells/well cultured for $24 \mathrm{~h}$ followed by treatment with $0,1,5$ and $10 \mu \mathrm{M}$ etomidate for $48 \mathrm{~h}$ at $37^{\circ} \mathrm{C}$. Subsequently the cells were trypsinized and replated in a 6-well plate with 500 cells/well. The cells were subsequently cultured for 21 days at $37^{\circ} \mathrm{C}$. During termination of the experiment, the cells were washed 3 times with PBS and were subsequently fixed for $10-12 \mathrm{~min}$ in $4 \%$ paraformaldehyde. Crystal violet $(0.06 \%)$ was used to stain $\left(30-60 \mathrm{~min}\right.$ at $\left.37^{\circ} \mathrm{C}\right)$ the live cells and the number of colonies ( $>50$ cells/colony) was counted under an inverted microscope using a camera (Olympus Corporation, Tokyo, Japan).

Reactive oxygen species (ROS) assay. In order to determine the effect of etomidate on the generation of ROS, $\mathrm{N} 2 \mathrm{a}$ cells at a cell count of $2.0 \times 10^{6}$ were seeded in 6 -well plates and maintained for $24 \mathrm{~h}$. Subsequently, the cells were treated with $0.5,1,5$ and $10 \mu \mathrm{M}$ etomidate for $48 \mathrm{~h}$. Finally, cells were collected in tubes, washed three times with $\mathrm{PBS}$ and then resuspended in $500 \mu \mathrm{l}$ PBS to which $10 \mu \mathrm{M}$ DCFH-DA was added and cells were incubated for $30 \mathrm{~min}$ in dark at $37^{\circ} \mathrm{C}$. ROS-induced green fluorescence of DCF-DA was imaged using 488-nm laser excitation. The laser power was set to $1-3 \%$. This power setting allowed complete discrimination of DCF fluorescence and the autofluorescence originating from the oxidized form of mitochondrial flavoproteins. The 515-530 nm emission range was used to monitor an increase in dichlorofluorescein, the oxidized product of DCF-DA.

Detection of apoptosis via Annexin V PI. Cells $\left(1 \times 10^{6}\right)$ were seeded in 50-ml dishes and incubated for $24 \mathrm{~h}$ at $37^{\circ} \mathrm{C}$. Subsequently etomidate at different concentration was added directly to the dishes and incubated for additional 24, 48 and 72 h. Cells were collected, washed with PBS and resuspended in PBS. Apoptotic cell death was identified by double

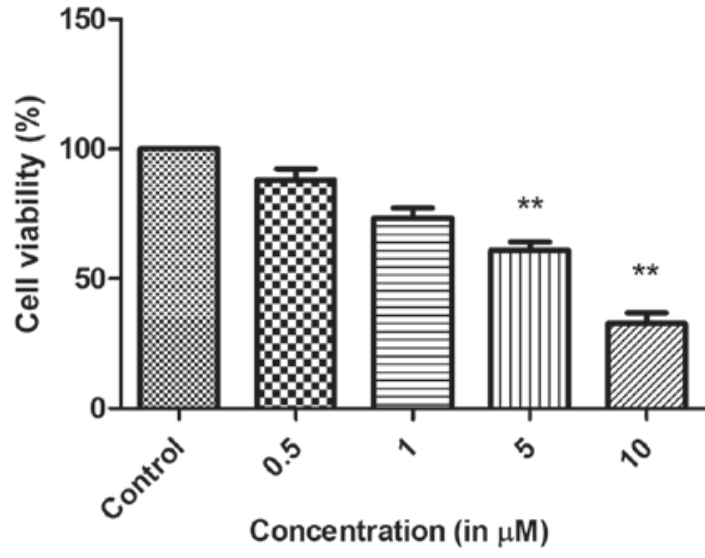

Figure 1. Etomidate inhibits N2a cell proliferation. Data are expressed in mean \pm standard error of the mean. ${ }^{* *} \mathrm{P}<0.05$ vs. control.

supravital staining with recombinant FITC-conjugated Annexin V and PI, using the Annexin V-FITC Apoptosis Detection kit (BD Biosciences) according to the manufacturer's protocol. Flow cytometry analysis was performed immediately following supravital staining. Data acquisition and analysis were performed in a Becton-Dickinson FACS Calibur flow cytometer using Cell Quest software (version 5.1; BD Biosciences).

Western blot analysis. In the $60 \mathrm{~mm}$ dishes, the N2a cells (at a density $2 \times 10^{6}$ ) were seeded and maintained for $24 \mathrm{~h}$ after which they were treated with $0.5,1,5$ and $10 \mu \mathrm{M}$ etomidate for 48 h. Cells were trypsinized and lysed using a radioimmunoprecipitation assay buffer (Abcam, Cambridge, MA, USA). Bradford method (Thermo Fisher Scientific, Inc.) was used for protein quantification, after which proteins were separated (10 $\mu \mathrm{g} / \mathrm{sample})$ by $12 \%$ SDS-PAGE and were then transferred at $100 \mathrm{~V}$ for $2 \mathrm{~h}$ onto a PVDF membrane. Blocking of the membrane was performed with $5 \%$ skimmed milk for $1 \mathrm{~h}$ to avoid non-specific binding of the antibodies. Membranes were incubated with primary antibodies: Caspase-3 (procaspase-3 and active caspase-3; cat. no. 9665; 1:1,000), caspase-9 (procaspase-9 and active caspase-9; cat. no. 9502; 1:1,000), poly ADP-ribose polymerase (PARP; cleaved PARP p89; cat. no. 9542; 1:1,000), $\beta$-actin (cat. no. 4967; 1:1,000) all from Cell Signaling Technology, Inc., (Beverly, MA, USA) at $4^{\circ} \mathrm{C}$ for $12-14 \mathrm{~h}$ after which membrane was washed twice with TBST for 5 min each. The secondary antibody, horseradish peroxidase-conjugated goat anti-mouse immunoglobulin G (IgG; cat. no. K0211589; 1:3,000; KOMA Biotech, Seoul, South Korea) was added at room temperature for $1 \mathrm{~h}$. The blots were analyzed with enhanced chemiluminescence detection system (GE Healthcare, Chicago, IL, USA) and visualized using a LAS 4000 (GE Healthcare, Chicago, IL, USA) imaging system and images were processed using ImageJ software (version 1.49; National Institutes of Health).

Statistical analysis. All experiments were performed in triplicate and data were presented as the mean \pm standard error of the mean. One-way analysis of variance or the independent samples Kruskal-Wallis $\mathrm{H}$ test, as appropriate 


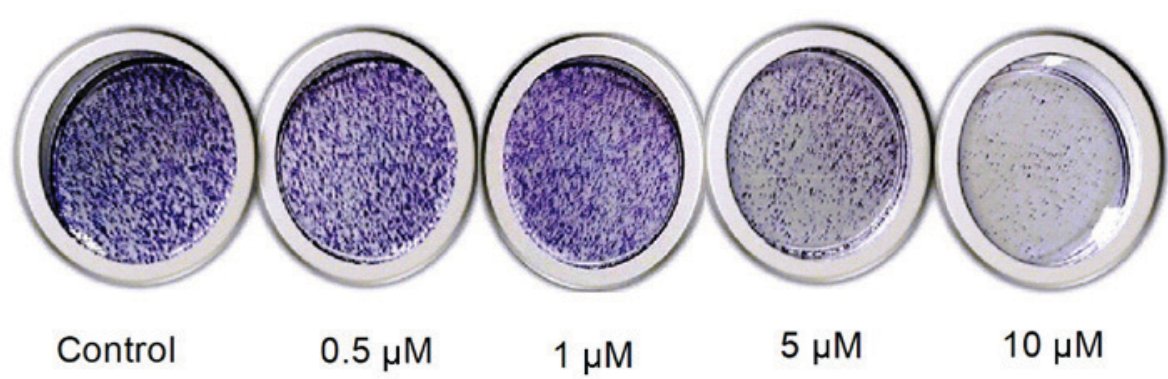

Figure 2. Effect of different etomidate concentrations on colony formation.

was used to compare differences among normally distributed variables. For statistically significant differences, post hoc pairwise comparisons were performed by using Tukey's honestly significant difference test or Dunn's test. $\mathrm{P}<0.05$ was considered to indicate a statistically significant difference.

\section{Results}

Inhibition of cell proliferation by etomidate in N2a cells. $\mathrm{N} 2 \mathrm{a}$ cells were first treated with a single concentration of etomidate $(20 \mu \mathrm{M})$ for $48 \mathrm{~h}$ and the cell viability was reduced up to $80 \%$ in $48 \mathrm{~h}$ (data not shown). For the $\mathrm{IC}_{50}$ value determination, the cells were treated with increasing concentrations of etomidate for $48 \mathrm{~h}$ in a 96 -well plate. The cell viability was reduced with increased etomidate concentration $(0.5,1,5$ and $10 \mu \mathrm{M})$. These findings demonstrated that $\mathrm{N} 2 \mathrm{a}$ cells responded to etomidate in a dose-dependent manner. The $\mathrm{IC}_{50}$ was determined as $5 \mu \mathrm{M}$ (Fig. 1). These findings collectively suggested that etomidate reduced the viability of N2a neuroblastoma cells.

Effect on colony formation. When N2a cells were treated with different concentrations of etomidate, the clonogenic potential of the cells reduced with the increase in etomidate concentration. This led to an inhibition of the colony formation potential of N2a cells in a dose-dependent manner as presented in Fig. 2.

Detection of apoptosis in N2a cells by Annexin V/PI staining. In order to confirm that etomidate induces apoptosis in N2a cells, Annexin V/PI assay was performed. The current study determined that etomidate increased the apoptotic population in a dose-dependent manner as presented in in Fig. 3. These finding sclearly indicated that etomidate induced concentration dependent apoptosis in N2a cells.

Effect of etomidateon generation of reactive oxygen species (ROS) in N2a cells. As a fore mentioned etomidate induced apoptosis in N2a cells; therefore, the current study investigated the effect of etomidate on the generation of reactive oxygen species using DCFH2-DA dye. Cells were treated with different concentrations of etomidate for $48 \mathrm{~h}$ and it was evident that etomidate treatment had a considerable impact on generation of reactive oxygen species in N2a cells as presented in Fig. 4. Therefore, these findings clearly indicated that etomidate induced generation of reactive oxygen species that led to apoptosis of N2a cells.
Mitochondrial membrane potential loss is induced by etomidatein $\mathrm{N} 2$ a cells. The current study investigated whether etomidate treatment of $\mathrm{N} 2 \mathrm{a}$ cells had any influence on mitochondrial membrane potential using Rodamine-123 dye. It was evident that etomidate treatment of N2a cells lead to loss of their mitochondrial membrane potential in a dose-dependent manner which led to quenching of the fluorescence when compared with the untreated cells which retained fluorescence. These findings confirmed that etomidate induced apoptosis in N2a cells by reducing the mitochondrial membrane potential of these cells (Fig. 5).

Etomidate induces PARP cleavage in N2a cells. In the present study, the effect of etomidate on the caspase activation and cleaving of PARP was investigated using western blotting. The N2a cells were treated with different concentrations of etomidate for $48 \mathrm{~h}$. An increase in the expression of cleaved PARP was observed in a dose dependent manner. There was also a decrease in the expression level of the initiator caspase (caspase-9), along with a decrease in the expression of procaspase- 3 in a dose-dependent manner. These findings suggested that etomidate induces apoptosis in a dose-dependent manner (Fig. 6).

\section{Discussion}

Surgery is one of the most common procedures used to treat patients in various diseases, including cancer $(20,21)$. However, to lessen the pain for the patients, sedatives or anesthetics are administered prior the medical procedures being performed $(22,23)$. Anesthesia is the induction of temporary loss of sensation or awareness (24). It is important as it aids in the execution of surgeries that may be otherwise impossible to be performed due to intolerable pain (24). The type of anesthesia administered to a patient depends upon the type of medical procedure that is to be performed on the patient during toothache, local anesthesia is administered that helps by blocking the transmission of the nerve impulse between the central nervous system and the tooth that is to be treated. During surgeries involving the removal of tumor mass from a patient with cancer, general anesthesia is administered, which leads to total suppression of central nervous system resulting in total lack of sensation and unconsciousness $(9,25)$. Etomidate is a drug that is administered as general anesthetic to patients. Etomidate is widely used due to easy dosing pattern and because it has no effect on the blood pressure of 

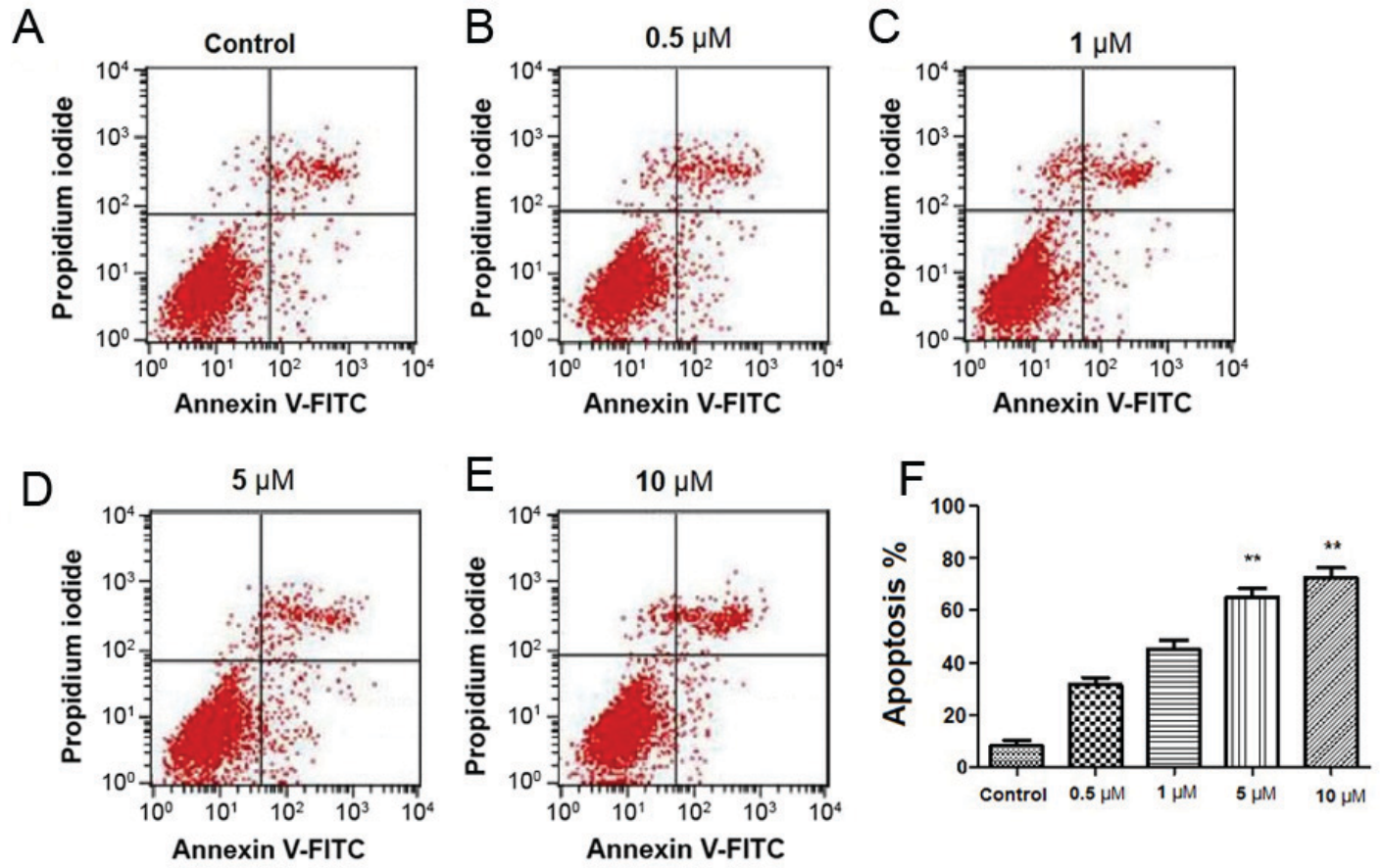

Figure 3. Apoptosis assay was performed with flow cytometry using PI and Annexin V-FITC double staining. Etomidate induced apoptosis in N2a cells in a concentration-dependent manner. N2a cells were treated with four different concentrations of etomidate (A) control, (B) 0.5 , (C) 1 , (D) 5 and (E) $10 \mu \mathrm{M}$. (F) Quanitifaction of \% apoptosis. Data are expressed in mean \pm standard error of the mean. ${ }^{* *} \mathrm{P}<0.05$ vs. control.
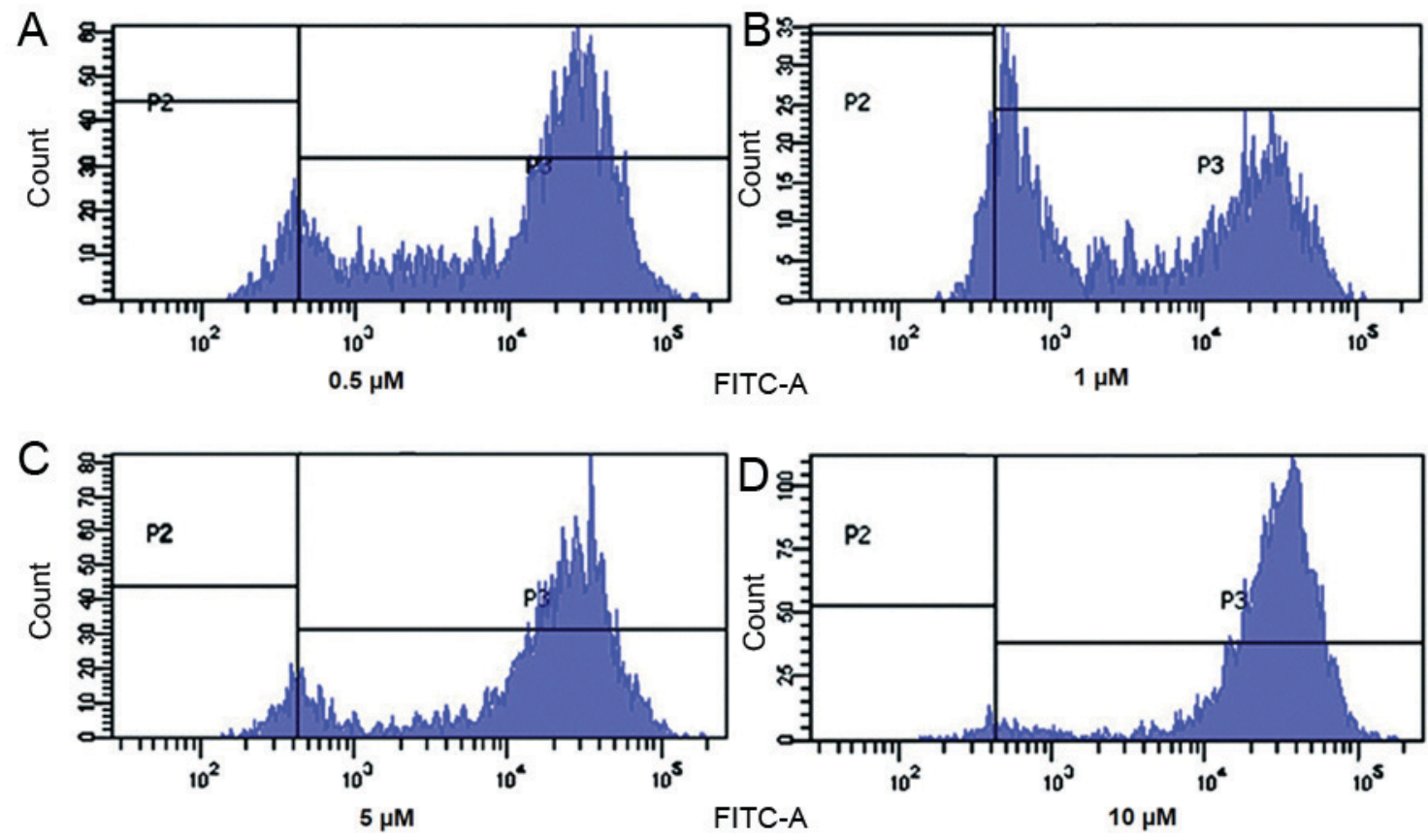

Figure 4. Etomidate treatment at concentration of (A) 0.5 , (B) 1 , (C) 5 and (D) $10 \mu \mathrm{M}$ led to generation of reactive oxygen species in N2a cells.

the patient $(26,27)$. Additionally, it also provides myocardial and cerebral ischemia protection, minimal suppression of ventilation and decrease in liberation of histamines $(15,28)$. To the best of our knowledge, whilst the way etomidate functions has been previously established, how etomidate exerts some of its cytotoxic effects remains to be determined. The present study revealed that anesthetic agent etomidate induces apoptosis in the N2a neuroblastoma cell line. The cells responded to etomidate in a concentration-dependent manner with increased cell death. In previous study, etomidate was identified to exert cytotoxic effect on RAW264.7 murine leukemia macrophage cell line (29). It has been determined that etomidate may lead to enhancement of apoptotic cell morphological changes and reduced cell viability in RAW264.7 cells. It also leads to an increase in expression of cytochrome $c$, apoptosis-inducing factor (AIF), endonuclease $\mathrm{G}$ (Endo G), caspase-9, caspase-3 active form and BCL2 associated X (Bax) proteins; however, it inhibited 

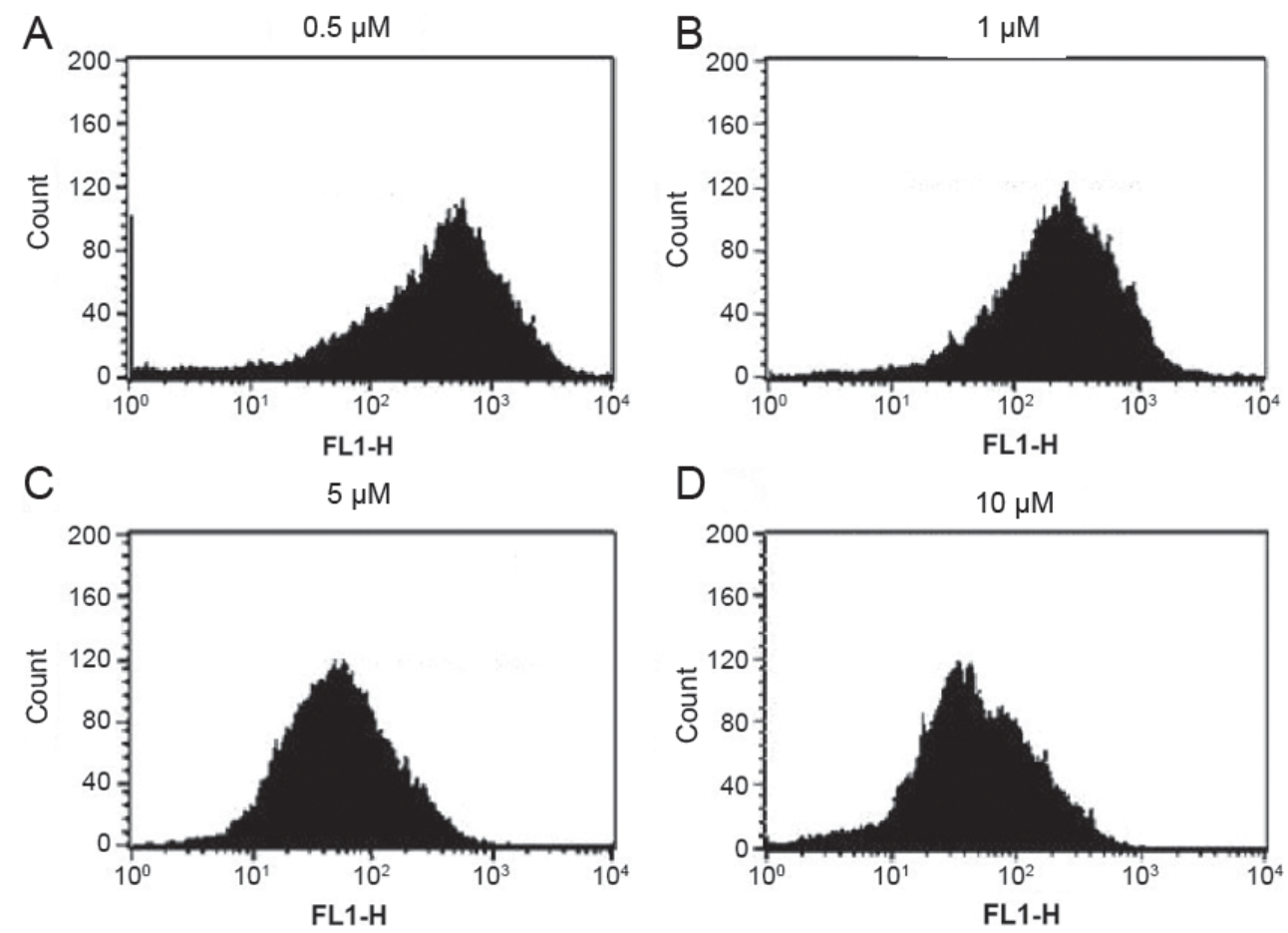

Figure 5. Etomidate treatment of N2a cells at concentration of (A) 0.5 , (B), (C) 5 and (D) $10 \mu \mathrm{M}$ reduced their mitochondrial membrane potential.

A

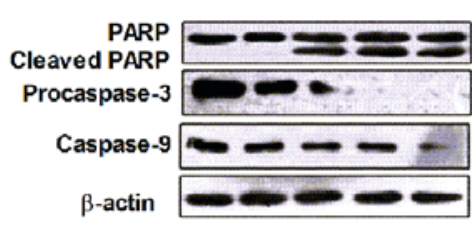

C

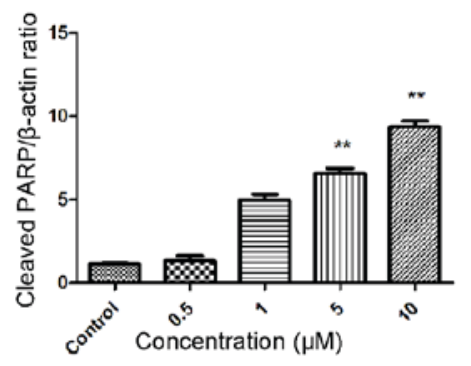

B

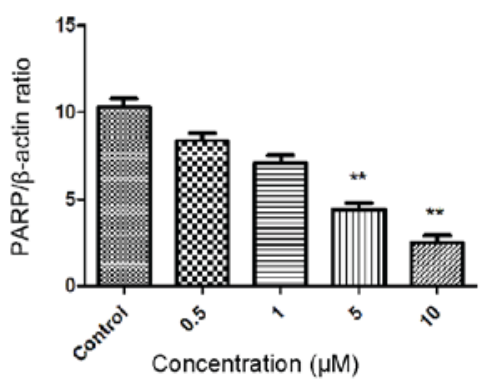

D

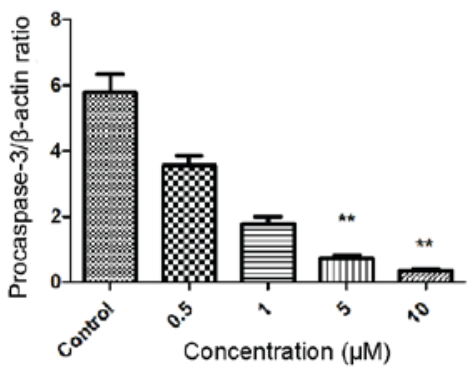

$\mathrm{E}$

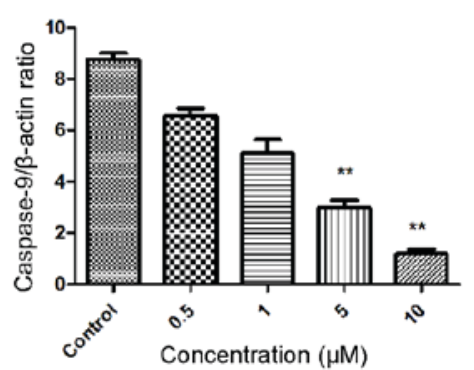

Figure 6. Western blot analysis of etomidate-treated samples. (A) Reperesentative western blotting image. Quantified expression levels of (B) PARP (C) cleaved PARP, (D) procaspase-3 and (E) caspase-9. Data are presented as the mean \pm standard error of the mean. ${ }^{* *} \mathrm{P}<0.05$ vs. control. PARP, poly ADP-ribose polymerase.

the expression of B cell leukemia/lymphoma 2 extra-large (Bcl-xL), leading to apoptosis (29). This would appear to be the case with etomidate viaa mitochondria-dependent pathway based on the change of the ratio of Bax/Bcl-xL which led to cytochrome c, AIF and Endo G, release from mitochondria (30-32). In present study, western blot analysis of etomidate-treated N2a cells revealed an decrease in the expression of pro-apoptotic proteins, such as initiator caspase-9 and procaspase-3. It was evident that there was an increase in the expression of cleaved PARP in a dose-dependent manner. Additionally, etomidate treatment led to generation of reactive oxygen species in N2a cells. Etomidate treatment also led to loss of mitochondrial membrane potential in $\mathrm{N} 2$ a cells.

In conclusion, the current study revealed that etomidate is an anesthetic drug that induces apoptosis in the $\mathrm{N} 2 \mathrm{a}$ 
neuroblastoma cell line. However, further studies in vitro and in vivo are required in order to confirm the cytotoxic effects of etomidate.

\section{Acknowledgements}

Authors would like to thank the Affiliated Foshan Hospital of Sun Yat-sen University (Guangdong, China) for providing the laboratory facility for the present study.

\section{Funding}

No funding was received.

\section{Availability of data and materials}

The datasets used and/or analyzed during the current study are available from the corresponding author on reasonable request.

\section{Authors' contributions}

JZ and ZYY conceived and designed the experiments and wrote the manuscript. HTC, YLF, MX, XQH and CL performed the experiments. BJL, LXF, XQH and LX analyzed the data.

\section{Ethics approval and consent to participate}

Not applicable.

\section{Consent for publication}

Not applicable.

\section{Competing interests}

The authors declare that they have no competing interests.

\section{References}

1. Ghoneim MM, Block RI, Haffarnan M and Mathews MJ: Awareness during anesthesia: Risk factors, causes and sequelae: A review of reported cases in the literature. Anesth Analg 108: 527-535, 2009.

2. Hsu GL, Hsieh CH, Chen HS, Ling PY, Wen HS, Liu LJ, Chen CW and Chua $\mathrm{C}$ : The advancement of pure local anesthesia for penile surgeries: Can an outpatient basis be sustainable? J Androl 28: 200-205, 2007.

3. Lee JS, Hayanga AJ, Kubus JJ, Makepeace H, Hutton M, Campbell DA Jr and Englesbe MJ: Local anesthesia: A strategy for reducing surgical site infections? World J Surg 35: 2596-2602, 2011

4. Breen P and Park KW: General anesthesia versus regional anesthesia. Int Anesthesiol Clin 40: 61-71, 2002.

5. Craig AD: Interoception: The sense of the physiological condition of the body. Curr Opin Neurobiol 13: 500-505, 2003.

6. Bery A, Cardona A, Martinez P and Hartenstein V: Structure of the central nervous system of a juvenile acoel, Symsagittifera roscoffensis. Dev Genes Evol 220: 61-76, 2010.

7. Koizumi O: Nerve ring of the hypostome in hydra: Is it an origin of the central nervous system of bilaterian animals? Brain Behav Evol 69: 151-159, 2007.

8. Mace SE: Central nervous system infections as a cause of an altered mental status? What is the pathogen growing in your central nervous system? Emerg Med Clin North Am 28: 535-570, 2010.

9. Uhrig L, Dehaene S and Jarraya B: Cerebral mechanisms of general anesthesia. Ann Fr Anesth Reanim 33: 72-82, 2014.
10. Bajwa S and Kulshrestha A: Dexmedetomidine: An adjuvant making large inroads into clinical practice. Ann Med Health Sci Res 3: 475-483, 2013.

11. Chohan AS: Anesthetic considerations in orthopedic patients with or without trauma. Top Companion Anim Med 25: 107-119, 2010.

12. Sarkiss M: Anesthesia for bronchoscopy and interventional pulmonology: From moderate sedation to jet ventilation. Curr Opin Pulm Med 17: 274-278, 2011.

13. Lü F, Lin J and Benditt DG: Conscious sedation and anesthesia in the cardiac electrophysiology laboratory. J Cardiovasc Electrophysiol 24: 237-245, 2013.

14. Hansson L, Zanchetti A, Carruthers SG, Dahlöf B, Elmfeldt D, Julius S, Ménard J, Rahn KH, Wedel H and Westerling S: Effects of intensive blood-pressure lowering and low-dose aspirin in patients with hypertension: Principal results of the Hypertension Optimal Treatment (HOT) randomised trial. HOT study Group. Lancet 351: 1755-1762, 1998

15. El-Khatib MF and Bou-Khalil P: Clinical review: Liberation from mechanical ventilation. Crit Care 12: 221, 2008.

16. Nedergaard $M$ and Dirnagl U: Role of glial cells in cerebral ischemia. Glia 50: 281-286, 2005.

17. Tavare AN, Perry NJ, Benzonana LL, Takata M and Ma D Cancer recurrence after surgery: Direct and indirect effects of anesthetic agents. Int J Cancer 130: 1237-1250, 2012.

18. Drlica K: Mechanism of fluoroquinolone action. Curr Opin Microbiol 2: 504-508, 1999.

19. Alonso-Castro AJ, Domínguez F and García-Carrancá A: Rutin exerts antitumor effects on nude mice bearing SW480 tumor. Arch Med Res 44: 346-351, 2013.

20. Duffy MJ: The war on cancer: Are we winning? Tumor Biol 34: 1275-1284, 2013.

21. De La Puerta B and Baines S: Surgical diseases of the genital tract in male dogs 1 . Scrotum, testes and epididymides. In Pract 34: 58-65, 2012.

22. Hansen TG: Sedative medications outside the operating room and the pharmacology of sedatives. Curr Opin Anaesthesiol 28: 446-452, 2015

23. Anderson SL, Duke-Novakovski T and Singh B: The immune response to anesthesia: Part 2 sedatives, opioids, and injectable anesthetic agents. Vet Anaesth Analg 41: 553-566, 2014.

24. Chamisha Y, Shamir MH, Merbl Y and Chai O: Reversible paralysis and loss of deep pain sensation after topical intrathecal morphine administration following durotomy. Vet Surg 44: 41-45, 2015

25. Dierdorf SF: Awareness during anesthesia. Anesthesiol Clin 14: 369-384, 1996.

26. de la Grandville B, Arroyo D and Walder B: Etomidate for critically ill patients. Con: Do you really want to weaken the frail? Eur J Anaesthesiol 29: 511-514, 2012.

27. Janouschek H, Nickl-Jockschat T, Haeck M, Gillmann B and Grözinger M: Comparison of methohexital and etomidate as anesthetic agents for electroconvulsive therapy in affective and psychotic disorders. J Psychiatr Res 47: 686-693, 2013.

28. Mendez-Tellez PA and Needham DM: Early physical rehabilitation in the ICU and ventilator liberation. Respir Care 57: 1663-1669, 2012.

29. Wu RS, Wu KC, Yang JS, Chiou SM, Yu CS, Chang SJ, Chueh FS and Chung JG: Etomidate induces cytotoxic effects and gene expression in a murine leukemia macrophage cell line (RAW264.7). Anticancer Res 31: 2203-2208, 2011.

30. Chiang JH, Yang JS, Ma CY, Yang MD, Huang HY, Hsia TC, Kuo HM, Wu PP, Lee TH and Chung JG: Danthron, an anthraquinone derivative, induces DNA damage and caspase cascades-mediated apoptosis in SNU-1 human gastric cancer cells through mitochondrial permeability transition pores and Bax-triggered pathways. Chem Res Toxicol 24: 20-29, 2011.

31. Yu FS, Yang JS, Yu CS, Lu CC, Chiang JH, Lin CW and Chung JG: Safrole induces apoptosis in human oral cancer HSC-3 cells. J Dent Res 90: 168-174, 2011.

32. Chen JC, Lu KW, Lee JH, Yeh CC and Chung JG: Gypenosides induced apoptosis in human colon cancer cells through the mitochondria-dependent pathways and activation of caspase- 3 . Anticancer Res 26: 4313-4326, 2006.

This work is licensed under a Creative Commons Attribution-NonCommercial-NoDerivatives 4.0 International (CC BY-NC-ND 4.0) License. 